\title{
High Dynamic Range Master Class com Matthew Goldman
}



Moderator: José Frederico Rehme

Education Director - Diretor de EngSET/ Positivo Universityaria da TVCi / Diretor de Ensino da SET

Speaker: Co-Moderator: Leonardo Chaves

Gerente de Tecnologia de Transmissão / TV GLOBO

\section{Speaker: Matthew Goldman}

Senior Vice President Technology at Ericsson / Fellow \& Executive Vice President at SMPTE / Senior Member at IEEE 


\title{
HIGH DYNAMIC RANGE MASTER CLASS COM MATTHEW GOLDMAN
}

\author{
Moderador: José Frederico Rehme
}

Education Director - Diretor de EngSET/ Positivo Universityaria da TVCi / Diretor de Ensino da SET

Speaker: Co-Moderador: Leonardo Chaves

Gerente de Tecnologia de Transmissão / TV GLOBO

\section{- High Dynamic Range Master Class}

\section{Speaker: MATTHEW GOLDMAN}

Senior Vice President Technology at Ericsson / Fellow \& Executive Vice President at SMPTE / Senior Member at IEEE

High Dynamic Range Master Class: Arguably the hottest new development in viewing experience since the introduction of color to television, High Dynamic Range (HDR) has taken the industry by storm. The level of realism it creates literally makes the viewer to say "wow", from large Ultra HD and HD displays to tablets and smart phones. This master class will explore in depth what HDR is and how it greatly increases the immersive viewing experience. The different schemes of perceptual quantizer and hybrid log gamma will be explained and how they impact the broadcaster workflows. Interoperability and backwards compatibility will be discussed, as well as the state of HDR standardization. Presentation time: 60 mins + Q\&A (suggest 10-15 mins). Audience: Engineers and technical management. 


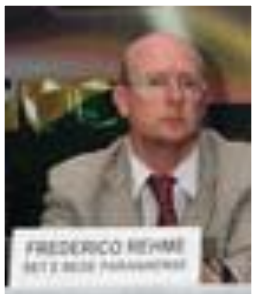

\section{JOSÉ FREDERICO REHME}

Education Director - Diretor de EngSET/ Positivo Universityaria da TVCi / Diretor de Ensino da SET

A graduate from UTFPR in Electrical Engineering - Electronics and Telecommunications in 1990 and an MSc. in 2007, defending the dissertation on the quality assessment of video over IP (Avaliação de Qualidade de Vídeo sobre Redes IP") He has worked at the RPC (the Paraná Communication Network) since 1986 as Telecom R\&D Coordinator. Member of SET as Education Director. His current work involves the implementation of Terrestrial Digital TV at RPC broadcasters and the dissemination of Digital TV through talks and mini courses to a range of audiences.

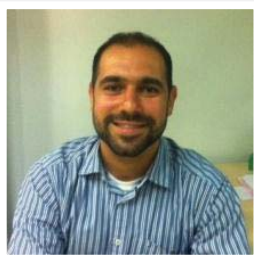

\section{LEONARDO CHAVES}

Gerente de Tecnologia de Transmissão / TV GLOBO

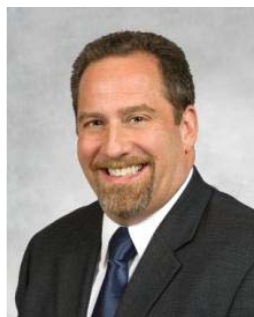

\section{MATTHEW GOLDMAN}

Senior Vice President Technology / Fellow and Executive Vice President / Senior Member Ericsson /SMPTE /IEEE

Matthew Goldman is Senior Vice President Technology, TV \& Media, at Ericsson, where he is dedicated to videoprocessing and media delivery solutions. He has been actively involved in the development of digital television systems since 1992. He played a leading role in the Moving Picture Experts Group (MPEG), in which he helped create the MPEG-2 Systems standard. Matthew Goldman has been influential in other industry organizations, including the Society of Motion Picture and Television Engineers (SMPTE), the Ultra HD Forum, the Advanced Television Systems Committee, the Digital Video Broadcasting project, and the Society of Cable Television Engineers. Recent activities include Ultra HD and High Dynamic Range technologies. Four of his projects have received the Technology and Engineering Emmy® Awards.

Matthew Goldman received his bachelor's degree (with high honors) and his Master's degree in Electrical Engineering from the Worcester Polytechnic Institute. He is the owner of six patents involving digital video transport. He is a Fellow of the SMPTE, a senior member of the IEEE, and an inductee of the Academy of Digital Television Pioneers. He is currently serving as Executive Vice President on the Board of Directors of the SMPTE 